\title{
Anti-immigrant Attitudes in the European Union: What Role for Values?
}

\author{
VYTENIS JUOZAS DEIMANTAS \\ Lithuanian Centre for Social Sciences, Institute of Sociology, 9 A. Goštauto Street, 01108 Vilnius, Lithuania \\ Netherlands Interdisciplinary Demographic Institute, Lange Houtstraat 19, 2511 CV, The Hague, The Netherlands \\ Royal Netherlands Academy of Arts and Sciences, Het Trippenhuis Kloveniersburgwal 29, 1011 JV Amsterdam, The Netherlands \\ University of Groningen, Grote Kruisstraat 2/1,9712 TS Groningen, The Netherlands \\ Email: vytenis.deimantas@lstc.lt
}

\begin{abstract}
This paper aims to analyse the connection between values individuals hold and perception whether immigration is bad or good for economy in the European Union. It applies the multilevel modelling approach on the European Social Survey rounds 1-7 and a set of the OECD economic measures. The method allows for an examination of personal (values, socioecomic and demographic) and contextual (GDP, inequality and unemployment rates) drivers of anti-immigrant tendencies. The results show that individual values are connected to how people perceive immigrants in the EU.
\end{abstract}

Keywords: immigration, attitudes, values, European Union, multi-level model

\section{INTRODUCTION}

Europe is a continent that celebrates its diversity. The diversity does not only come from 44 countries, hundreds of languages or ethnicities, it also arises from values of the "European way of life' (von der Leyen 2019a: 15). It translates to political, societal and cultural outcomes in Europe and affects its standing in the world (von der Leyen 2019b: 4).

Internally, one of the pillars of the European Union (EU) is the freedom of movement that allows European citizens to travel and work across the continent. Hundreds of thousands of people exercised this freedom when Central and Eastern Europeans migrated to the West looking for a better life (Penninx 2018; Van Mol, De Valk 2016). Externally, immigrant flow to Europe from former colonies and guest worker programmes enabling people from outside Europe to move to the continent shaped migration in the 20th century (El-Enany 2020; Penninx 2018). More recently, the European migrant crisis has led to a massive influx of immigrants to the EU. Only in 2015 more than a million refugees reached the EU constituting the largest ever inflow of asylum seekers in Europe (PEW 2016).

These tendencies show how deeply migration is entrenched in the social and institutional fabric of the EU. Yet immigration from within or outside of the EU has not been necessarily received favourably. At the extreme, EU immigration has been perceived as one of the reasons for the United Kingdom to vote to leave the EU (Gietel-Basten 2016). The anti-immigration sentiment is not a new phenomenon. For instance, anti-immigrant policies in the Americas 
have been found to be largely explained by economic measures of inequality, real GDP growth and unemployment (Timmer, Williamson 1998).

However, research following the economic rationale has several limitations. In such analyses, country level economic variables (e.g. average wages, migrant average wages, unemployment, etc.) are seen as major drivers for the anti-immigration sentiments. Yet the connection between individual attitudes and government policies against immigrants is rarely looked at. This line of literature also overlooks cultural aspects that influence the attitudes of the population. Depending on the place of origin, immigrants bring new traditions, habits, religions and languages to their host countries. Increasing cultural heterogeneity in the society may result in a back-clash against the minorities (Ivarsflaten 2008).

Therefore, in this paper we raise a question whether not only economic circumstances, but also individual values can be associated with anti-immigration sentiments in the EU. This relationship has scarcely been explored outside the matters of regional disparities (Czaika, Di Lillo 2018) and ethnic or religious affiliations of immigrants (Ramos et al. 2021; Gusciute et al. 2020). Therefore we seek to provide a closer look at individual values as a basis of anti-immigrant feelings. We employ the multi-level modelling approach which allows us to fit a regression to individual measurements while accounting for systematic unexplained variation among the countries of the EU. In this paper, we use the personal level data of the European Social Survey (ESS) 1-7 round complemented by the macro level data of the Organisation for Economic Co-operation and Development (OECD).

\section{SOCIO-ECONOMIC AND CULTURAL REASONS FOR ANTI-IMMIGRATION ATTITUDES}

The body of literature on anti-immigrant attitudes holds numerous pieces of work derived from the (socio-)economic point of view. In line with the trade theory, an influx of new labour force from migration is expected to reduce the average wage and increase profits in industry while migrant workers would crowd out native employment (Borjas 2003). Empirical findings show that a $1 \%$ increase in the migrant participation in the labour market decreases the wages of native-born people by $0.11 \%$ (Longhi et al. 2005).

Nevertheless, immigrants and domestic labourers with material interests compete for resources. Effectively this causes a blame-game between the groups for economic loss and discrimination. Golder (2003) argues that populist parties exploit these grievances by suggesting that economic hardship comes from minorities or immigrants. At the individual level, these economic grievances tend to be supported by a higher likelihood to vote for far-right parties among lower educated older persons (Scheve, Slaughter 2001). Similarly, less educated people with lower income tend to be against migration while higher income and better educated individuals take the opposite stance (Borjas 2014).

Second, economic background has been shown to be an important predictor. Inglehart and Norris (2016) argue that rising inequality in western societies contributes to populist voting as voters seek for opportunities to express their dissatisfaction and obtain a more substantial policy package. In addition, the authors indicate that the opening of world market and increasing competition for jobs create groups of people who cannot adapt to the new game rules and become globalisation losers.

The cultural explanation of anti-immigrant attitudes lies on the social identity theory (Tajfel, Turner 1979). It assumes that individuals naturally associate themselves with similar individuals. Furthermore, a person seeks self-esteem which they exercise by championing their group and rejecting the opposing group. Ivarsflaten (2008) argues that immigration 
brings cultural differentiation into a society, hence creating opportunities for anti-immigrant sentiments to manifest.

At the individual level, cultural grievances and anti-immigrant attitudes are related to populist party support (e.g. van der Brug et al. 2005; Norris 2005; Ivarsflaten 2008). However, it is important to recognise that anti-immigrant attitudes do not necessarily translate into anti-immigrant behaviour. Blinder et al. (2013) shows that even though some Europeans may hold anti-immigrant sentiments they do not necessarily vote for far-right parties as it is considered to be socially unacceptable. Yet these norms vary across countries.

Changes in cultural attitudes that happened in the past couple of decades are seen as threats to the traditional way of life to certain groups within western societies (Inglehart, Norris 2016). The shift from traditional values that were practiced by more or less homogenous group of people to liberal and individualised moral standards in a diverse society is often associated with immigrants and their different lifestyles. This association exacerbates cultural back-clash against the immigrants. For instance, anti-immigrant attitudes can be seen as a 'silent counter-revolution'. Post-materialist values of individual freedom, gender and racial equality as well as sexual freedom are usually opposed by populist parties. People who share more conservative views manifest them through support for populists in this way creating a 'back-clash' (Ignazi 1992).

Lastly, socio-economic and cultural reasons are heterogenous across Europe. Even if anti-immigrant sentiment has been identified in all European countries (Czaika, Di Lillo 2018) and usually arises from aspects of race (Czaika, Di Lillo 2018), ethnicity (Ramos et al. 2021) and religion (Gusciute et al. 2020), Central and Eastern European countries are much less welcoming to immigrants than Western countries indicating a potential role for values (Czaika, Di Lillo 2018).

\section{DATA}

The primary source of data used in this paper is obtained from the European Social Survey (ESS), rounds 1-7, which allow us to explore the cross-national micro level data. The core module of the ESS displays dynamics in a wide range of social variables that include but are not limited to social and institutional trust, political orientations, government role in public life, moral, political and social value, religious affiliation and demographics. Selected rounds were conducted in the period between 2002 and 2014 in 32 European countries $25^{*}$ of which were EU member states at the point of data collection and are used in the analysis later. In addition, the ESS rounds 6 and 7 correspond to the last intra-European migrant flow caused by the financial crisis and the inception of the refugee crisis. A few previous studies that focused on anti-immigrant attitudes used the European Social Survey (e.g. Mau, Burkhardt 2009; Söderlund, Kestilä-Kekkonen 2009; Inglehart, Norris 2016).

To complement the ESS data, we include additional data from the OECD. The latter data measures the GDP per capita and the unemployment rate in the 25 European countries as well as accounts for the inequality (GINI index). We use the OECD data that corresponds to the same period and countries as in the initial ESS data set.

Austria, Belgium, Bulgaria, Croatia, Cyprus, the Czech Republic, Denmark, Estonia, Finland, France, Germany, Greece, Hungary, Ireland, Italy, Lithuania, Luxembourg, the Netherlands, Poland, Portugal, Slovakia, Slovenia, Spain, Sweden and the United Kingdom. 


\section{METHODS}

To start with, the multi-level model allows us to fit a regression model to the individual measurements while accounting for systematic unexplained variation among the 25 countries of the EU. The model can be expanded in many ways by adding more predictors at the individual and country levels and by allowing the slope and the intercept to vary by country.

In this particular case, nested data of individuals in countries permits to make inference without a need to pick one certain level of analysis. Moreover, it goes beyond the traditional linear view that assumes same effects on different groups. The multi-level model can capture and estimate the measurement difference among different groups. In this instance it applies to the anti-immigrant attitudes across different EU countries.

The dependent variable measures the perception of whether immigration is bad or good for the country's economy with values from 0 to 10 . Values from 0 to 5 represent negative attitudes while values from 5 to 10 are positive ones.

In order to select individual level covariates, we rely on the previous work on ethnic prejudice and attitudes towards immigrants. Education is known to play an important role in defining the attitudes towards foreigners. The higher the attained education level, the more welcoming people get (Coenders, Scheepers 2003). The education of an individual is represented in 5 groups from 'less than lower secondary education' to 'tertiary education completed. We also include a dummy variable that measures if an individual is a citizen of the country (1) or not (0) where having a citizenship is expected to have a negative association with attitudes towards immigrants. We as well add control variables of gender, age and age squared. Age variables are coded metrically while gender is a dummy variable where 1 is male. These variables were found significant in other attitude studies before (e.g. Inglehart, Norris 2016).

The main focus of this paper is the connection between values and attitudes towards immigrants. Hence, the following variables are used. We employ a variable that measures how religious an individual is in the 11 point scale from 0 (not religious at all) to 10 (very religious). It has been previously shown that less religious people are more tolerant towards other ethnic groups (Inglehart, Norris 2016). A variable that represents the individual location on the political left-right scale from 0 (left) to 10 (right) is used as well. Previous findings show that people with left-leaning beliefs are more prone to accepting immigrants as opposed to right-leaning ones (Raijman et al. 2003). In line with the claim that liberal values create grievances for certain groups in society that later may express their dissatisfaction by voting for xenophobic parties, we introduce a variable that measures if the individual agrees that gays and lesbians are free to live life as they wish in the scale from 1 (agree strongly) to 5 (disagree strongly) (Inglehart, Norris 2016). Lastly, standard country level variables that measure the log GDP, inequality (GINI) and total unemployment levels are included (Azzollini 2021; Anderson, Singer 2008). The logged GDP is measured in US\$ per capita, inequality is captured by the GINI coefficient, and the unemployment variable refers to the total number of unemployed seeking for jobs in a country. We indicate that the higher GDP and lower GINI have a positive impact on welcoming immigrants whilst unemployment measure is expected to have the opposite impact.

\section{MULTI-LEVEL MODEL ANALYSIS}

Our goal is to shed light on the connection between individual values and the way immigrants are seen in society. We control several individual and country level factors by running a number of regressions using the dependent variable of 'immigration bad or good for country's economy' and independent variables on individual level of gender, age, education and citizenship. 
In the second step, we add the macro level variables of GDP, inequality and unemployment to check whether multi-level modelling is suitable for the case. Lastly, we include the individual level value variables. These steps allow us to control relevant contextual factors and evaluate the connection between individual values and attitudes towards immigrants. Table 1 reports descriptive statistics of all variables employed in the multilevel analysis.

Table 1. Descriptive statistics

\begin{tabular}{|c|c|c|c|c|}
\hline & Mean & Standard deviation & Minimum & Maximum \\
\hline \multicolumn{5}{|l|}{ Level 1: Individual variables } \\
\hline Age & 51.583 & 43.12 & 13 & 123 \\
\hline $\mathrm{Age}^{2}$ & 2660.826 & 1859.387 & 169 & 15129 \\
\hline Gender $(1=$ male $)$ & 0.5375247 & 0.4985908 & 0 & 1 \\
\hline Education & 3.159094 & 2.898632 & 1 & 5 \\
\hline Citizen $(1=$ yes $)$ & 0.9600285 & 0.1958927 & 0 & 1 \\
\hline \multicolumn{5}{|l|}{ Value variables } \\
\hline $\begin{array}{c}\text { Religious }(0=\text { not religious, } 10=\text { very } \\
\text { religious })\end{array}$ & 4.706123 & 3.015653 & 0 & 10 \\
\hline Left-right scale $(0=$ left, $10=$ right $)$ & 5.069268 & 2.187106 & 0 & 10 \\
\hline $\begin{array}{c}\text { Gays and lesbians live as they wish } \\
(1=\text { agree strongly, } 5=\text { disagree strongly })\end{array}$ & 2.226841 & 1.178575 & 1 & 5 \\
\hline Cases (unweighted) & 269,556 & 269,556 & 269,556 & 269,556 \\
\hline \multicolumn{5}{|l|}{ Level 2: Country variables } \\
\hline GDP (in $\log$ ) & 10.30755 & 0.334037 & 9.029137 & 11.52748 \\
\hline Inequality (GINI) & 0.2989286 & 0.0336484 & 0.234 & 0.384 \\
\hline Unemployed seeking for job (total) & 0.046861 & 0.0156754 & 0.0175714 & 0.0950264 \\
\hline Cases (unweighted) & 25 & 25 & 25 & 25 \\
\hline
\end{tabular}

Source: ESS 1-7, OECD, own calculations.

The results of the multilevel analyses are provided in Table 2. Model 1 shows what factors have an effect on seeing immigration as bad for the country's economy. Looking at the individual level variables, it is possible to say that older men perceive immigration unfavourably. Moreover, being a citizen of the country has a strong negative connection as well. By contrast, individuals with higher education seem to be more welcoming towards immigrants.

The results are aligned with the earlier scholarship on attitudes concerning the immigrants. We hold an assumption that a part of variance disparities between the countries can be better understood by looking at the variance within the countries. A much larger part of the variance can be found at the individual rather than the macro level. This could be interpreted as an indication that the macro variables can only explain the variance to a narrower extent in comparison to the micro variables. However, this model allows for an estimation of the relationship between the macro level variables and the variable that measures if 'immigration bad or good for country's economy'. 
Table 2. Multi-level analyses of the relationship between attitudes towards immigrants and individual and country level variables

\begin{tabular}{|c|c|c|c|}
\hline & Model 1 & Model 2 & Model 3 \\
\hline \multicolumn{4}{|l|}{ Level 1: Individual variables } \\
\hline \multirow[t]{2}{*}{ Age } & $-0.00097^{\star * *}$ & $-0.01014^{* * *}$ & $0.00692^{\star * *}$ \\
\hline & $(0.0036)$ & $(0.0036)$ & $(0.0038)$ \\
\hline \multirow[t]{2}{*}{$\operatorname{Age}^{2}$} & $-0.0000949^{\star * *}$ & $-0.000103^{* * *}$ & $-0.0000479^{\star * *}$ \\
\hline & $(0.0000133)$ & $(0.0000135)$ & $(0.0000146)$ \\
\hline \multirow[t]{2}{*}{ Gender $(1=$ male $)$} & $-0.2565777^{\star * *}$ & $-0.2667285^{\star * *}$ & $-0.3723111^{\star * *}$ \\
\hline & $(0.0093172)$ & $(0.009494)$ & $(0.0101578)$ \\
\hline \multirow[t]{2}{*}{ Education } & $0.0724831^{\star * *}$ & $0.0721698^{* * *}$ & $0.0706372^{\star * *}$ \\
\hline & $(0.0016398)$ & $(0.0016509)$ & $(0.0017543)$ \\
\hline \multirow[t]{2}{*}{ Citizen $(1=$ yes $)$} & $-1.053048^{\star * *}$ & $-1.049854^{\star * *}$ & $-1.000161^{\star * *}$ \\
\hline & $(0.1220147)$ & $(0.0246059)$ & $(0.0273505)$ \\
\hline \multicolumn{4}{|l|}{ Value variables } \\
\hline \multirow[t]{2}{*}{ Religious $(0=$ not religious, 10 = very religious $)$} & & & $0.0501478^{* * *}$ \\
\hline & & & $(0.0018569)$ \\
\hline \multirow{2}{*}{ Left-right scale ( $0=$ left, $10=$ right $)$} & & & $-0.0486973^{\star * *}$ \\
\hline & & & $(0.0023816)$ \\
\hline \multirow[t]{2}{*}{$\begin{array}{l}\text { Gays and lesbians live as they wish }(1=\text { agree } \\
\text { strongly, } 5=\text { disagree strongly })\end{array}$} & & & $-0.3420808^{\star * *}$ \\
\hline & & & $(0.0049548)$ \\
\hline \multicolumn{4}{|l|}{ Level 2: Country variables } \\
\hline \multirow[t]{2}{*}{ GDP (in log) } & & $0.8612182^{\star *}$ & 0.5750897 \\
\hline & & $(0.2857999)$ & $(0.2938365)$ \\
\hline \multirow[t]{2}{*}{ Inequality (GINI) } & & 1.483984 & 2.161138 \\
\hline & & $(3.196033)$ & $(3.215943)$ \\
\hline \multirow[t]{2}{*}{ Unemployed seeking for job (total) } & & -0.7989907 & -3.581870 \\
\hline & & $(10.68556)$ & $(10.6929)$ \\
\hline \multirow[t]{2}{*}{ Intercept } & $5.920301^{\star * \star}$ & -3.288994 & 0.3595797 \\
\hline & $(0.1220147)$ & $(3.366566)$ & $(3.462331)$ \\
\hline \multirow[t]{2}{*}{ Between-country variance } & 0.5786033 & 0.4791514 & 0.4792891 \\
\hline & $(0.0820502)$ & $(0.0726553)$ & $(0.0731104)$ \\
\hline \multirow[t]{2}{*}{ Within-country variance } & 2.341649 & 2.341636 & 2.319072 \\
\hline & $(0.003281)$ & $(0.003281)$ & $(0.0033435)$ \\
\hline Intraclass correlation (rho) & 0.0575414 & 0.0431559 & 0.0409414 \\
\hline
\end{tabular}

Note: $N=269,556, n=25$; unstandardised coefficients, year fixed effects included, standard errors in parentheses; significance levels: ${ }^{*} p<0.05 ;{ }^{* *} p<0.01 ;{ }^{* *} p<0.001$. Empty model: intercept: $4.783891{ }^{* * *}(0.1228359)$; within-country variance: 2.372527 (0.0033109); between country variance: 0.6136079 (0.0870091); intraclass correlation: 0.062696. Source: ESS 1-7, OECD, own calculations. 
Including the GDP, GINI and unemployment rate explains a larger part of variance at the micro level. From Model 2 we see that the addition of these variables has decreased the variance between countries indicating that these variables can explain a part of the variance. In addition, we see that the intraclass correlation ( $r h o$ ) has decreased from 0.0575414 in Model 1 without the macro level variables to 0.0409414 in Model 2 with the macro level variables. This proves that we can proceed with the multi-level model specification. Moreover, we find the following structural effects. First, a higher GDP is positively associated with attitudes towards immigrants. Second, higher inequality does not exacerbate negative attitudes towards immigrants. On the contrary, inequality can be seen to have a positive effect on thinking that immigrants make the country better economically. Third, a negative association is exhibited by the unemployment variable. However, these estimates are statistically insignificant. The direction of other variable estimates remains unchanged by inclusion of country level variables. Older men with citizenship have a more negative attitude towards migrants. Education remains positively associated with more welcoming attitudes towards immigrants.

By including the value variables on the individual level we seek to expand the structural and compositional effect basis from Models 1 and 2. In Model 3, we establish a connection between a person's values and attitudes. We see that contrary to expectations being religious has a positive association with attitudes towards immigrants. Furthermore, having right-wing political preferences and thinking that gays and lesbians cannot lead their lives as they wish affects the attitudes towards immigrants negatively. Other individual level variables remain virtually unchanged apart from the numerical change in the age ${ }^{2}$ coefficient which has halved. However, country level effects were all found to be insignificant. It permits stressing the importance of adding value measures to the analysis. This is visible from the reduced between-country variance after the inclusion of the individual value variables. A similar conclusion can be drawn from the reduction of the intraclass correlation when new variables are added.

\section{CONCLUSIONS}

The aim of this study is to answer the question whether individual values rather than economic performance of a country can be associated with attitudes towards immigrants in the EU. We looked at this subject by analysing the data from the OECD and the ESS rounds 1-7 that was drawn from the subset of 25 European Union member states.

Supporting the previous work (e.g. Scheve, Slaughter 2001), we found that older and less educated men, who are citizens of the country, are more prone to negative views towards immigrants. With regard to the value variables, we established that identifying with the right-wing politics and having prescriptive views on gay and lesbians' lives has a negative connection with the attitudes towards immigrants. These findings stand in line with the previous work on anti-immigrant attitudes (e.g. Inglehart, Norris 2016). Essentially this supports the theory of cultural grievances and the back-clash against the new values that come with economic modernisation. People who identify themselves with the right-wing politics tend to represent traditional values more than the ones who define themselves by left-wing values. In the end, it is possible to say that these findings support the 'back-clash' (Ivarsflaten 2008). Right-leaning people with more conservative and prescriptive values tend to have more pronounced negative attitudes towards immigrants and their impact on the country's economy. 
However, contrary to expectations, religiousness was found to be associated with thinking that immigrants make the country a better place. Arguably this finding can be explained by the quality to which the religion is practiced. Assuming that a religious individual systematically follows the teachings of their religion, it would be possible to direct the link to the quality of religiousness having a positive connection to attitudes towards immigrants. Yet, this assumption needs further investigation.

The purpose of the paper was to show the importance of individual values alongside other established variables that define attitudes towards immigrants. For this matter, we have evaluated the association of macro level measures with the attitudes towards immigrants as it has been previously done in the literature (e.g. Timmer, Williams 1998; Coender, Scheepers 2003; Mau, Burkhardt 2009). We found that the log GDP, total unemployment and inequality are not significantly associated with attitudes towards immigrants. This opposes the findings of Timmer and Williams (1998) who characterised the anti-immigrant sentiment in the society as solely a problem defined by economic factors. These findings allow us to see a more holistic view of what shapes attitudes towards immigrants.

Received 14 April 2021

Accepted 23 November 2021

\section{References}

1. Anderson, C. J.; Singer, M. M. 2008. 'The Sensitive Left and the Impervious Right: Multilevel Models and the Politics of Inequality, Ideology, and Legitimacy in Europe', Comparative Political Studies 41(4-5): 564-599.

2. Azzollini, L. 2021. 'The Scar Effects of Unemployment on Electoral Participation: Withdrawal and Mobilization Across European Societies', European Sociological Review.

3. Blinder, S.; Ford, R.; Ivarsflaten, E. 2013. 'The Better Angels of our Nature: How the Antiprejudice Norm Affects Policy and Party Preferences in Great Britain and Germany', American Journal of Political Science 57(4): 841-857.

4. Borjas, G. J. 2003. 'The Labor Demand Curve is Downward Sloping: Reexamining the Impact of Immigration on the Labor Market', The Quarterly Journal of Economics 118(4): 1335-1374.

5. Borjas, G. J. 2014. Immigration Economics. Harvard University Press.

6. Bustikova, L. 2014. 'Revenge of the Radical Right', Comparative Political Studies 47(12): 1738-1765.

7. Coenders, M.; Scheepers, P. 2003. 'The Effect of Education on Nationalism and Ethnic Exclusionism: An International Comparison', Political Psychology 24(2): 313-343.

8. Czaika, M.; Di Lillo, A. 2018. 'The Geography of Anti-immigrant Attitudes Across Europe, 2002-2014', Journal of Ethnic and Migration Studies 44(15): 2453-2479.

9. El-Enany, N. 2020. (B)ordering Britain: Law, Race and Empire. Manchester University Press.

10. Gietel-Basten, S. 2016. 'Why Brexit? The Toxic Mix of Immigration and Austerity', Population and Development Review 42(4): 673-680.

11. Gusciute, E.; Mühlau, P.; Layte, R. 2020. 'All Welcome Here? Attitudes towards Muslim Migrants in Europe', International Migration 59(1).

12. Ignazi, P. 1992. 'The Silent Counter-Revolution: Hypotheses on the Emergence of Right-Wing Parties in Europe', European Journal of Political Research 22(1): 3-34.

13. Inglehart, R.; Norris, P. 2016. Trump, Brexit, and the Rise of Populism: Economic Have-nots and Cultural Backlash. HKS Faculty Research Working Paper Series RWP16-026.

14. Longhi, S.; Nijkamp, P.; Poot, J. 2005. 'A Meta-Analytic Assessment of the Effect of Immigration on Wages', Journal of Economic Surveys 19(3): 451-477.

15. Mau, S.; Burkhardt, C. 2009. 'Migration and Welfare State Solidarity in Western Europe', Journal of European Social Policy 19(3): 213-229.

16. Norris, P. 2005. Radical Right: Voters and Parties in the Electoral Market. Cambridge, UK: Cambridge University Press. 
17. Penninx, R. 2018. 'Old Wine in New Bottles? Comparing the Post-War Guest Worker Migration and the Post 1989 Migration from CEE-Countries to EU-Member Countries', in Between Mobility and Migration. Cham: Springer, 77-97.

18. PEW. 2016. Number of Refugees to Europe Surges to Record 1.3 Million in 2015. Available at: https://www. pewresearch.org/global/2016/08/02/number-of-refugees-to-europe-surges-to-record-1-3-millionin-2015/

19. Raijman, R.; Semyonov, M.; Schmidt, P. 2003. 'Do Foreigners Deserve Rights? Determinants of Public Views towards Foreigners in Germany and Israel', European Sociological Review 19(4): 379-392.

20. Ramos, M.; Thijssen, L.; Coenders, M. 2021. 'Labour Market Discrimination Against Moroccan Minorities in the Netherlands and Spain: A Cross-national and Cross-Regional Comparison', Journal of Ethnic and Migration Studies 47(6): 1261-1284.

21. Rydland, L. T.; Arnesen, S.; Østensen, Å. G. 2008. Contextual Data for the European Social Survey. An Overview and Assessment of Extant Sources. Bergen, Norway: Norwegian Social Science Data Services (NSD).

22. Scheve, K. F.; Slaughter, M. J. 2001. 'Labor Market Competition and Individual Preferences over Immigration Policy', The Review of Economics and Statistics 83(1): 133-145.

23. Söderlund, P.; Kestilä-Kekkonen, E. 2009. 'Dark Side of Party Identification? An Empirical Study of Political Trust Among Radical Right-Wing Voters', Journal of Elections, Public Opinion and Parties 19(2): $159-181$.

24. Tajfel, H.; Turner, J. C. 1979. 'An Integrative Theory of Intergroup Conflict', The Social Psychology of Intergroup Relations 33(47): 74.

25. Timmer, A. S.; Williams, J. G. 1998. 'Immigration Policy Prior to the 1930s: Labor Markets, Policy Interactions, and Globalization Backlash', Population and Development Review: 739-771.

26. Van der Brug, W.; Fennema, M.; Tillie, J. 2005. 'Why Some Anti-Immigrant Parties Fail and Others Succeed: A Two-Step Model of Aggregate Electoral Support', Comparative Political Studies 38(5): 537-573.

27. Van Mol, C.; De Valk, H. 2016. 'Migration and Immigrants in Europe: A Historical and Demographic Perspective', in Integration Processes and Policies in Europe. Cham: Springer, 31-55.

28. Von der Leyen, U. 2019a. A Union That Strives for More my Agenda for Europe. Available at: https://ec.europa.eu/commission/sites/beta-political/files/political-guidelines-next-commission_en.pdf

29. Von der Leyen, U. 2019b. Mission Letter to Dubravka Šuica. Available at: https://ec.europa.eu/commission/ sites/beta-political/files/mission-letter-dubravka-suica_en.pdf

VYTENIS JUOZAS DEIMANTAS

\title{
Asmeninès vertybès ir jų ryšys su priešimigrantinėmis nuostatomis Europos Sąjungoje
}

\author{
Santrauka \\ Straipsnio tikslas - ištirti ryši tarp asmeninių vertybių ir nusiteikimo prieš imigran- \\ tus Europos Sąjungoje. Naudojant Europos socialinio tyrimo 1-7 bangų ir Ekonominio \\ bendradarbiavimo ir pletros organizacijos rodiklius, straipsnyje pritaikoma daugiapa- \\ kopio modelio metodologija. Ši metodologija leidžia ịvertinti asmenines (vertybines, \\ socioekonomines ir demografines) bei kontekstines (bendrojo vidaus produkto, ne- \\ darbo lygio, nelygybès) priežastis, nulemiančias neigiamą požiūrị i i imigrantus. Tyrimo \\ rezultatai rodo, kad Europos Sąjungoje asmeninès vertybès yra susijusios su požiūriu ị \\ imigrantus.
}

Raktažodžiai: imigracija, nuostatos, vertybès, Europos Sąjunga, daugiapakopis modelis 